\title{
PENGARUH STRATEGI PEMBELAJARAN DAN GAYA BELAJAR TERHADAP HASIL BELAJAR FISIKA SISWA
}

\author{
Zulhamdi $^{1}$, Abdul Muin Sibuea ${ }^{2}$, Syarifuddin ${ }^{3}$ \\ ${ }^{1}$ Sekolah Menengah Atas Negeri 1 Air Putih, Batubara, Sumatera Utara \\ ${ }^{2,3}$ Program Pascasarjana Universitas Negeri Medan \\ ${ }^{1}$ zulhamdi@gmail.com, ${ }^{2}$ muin_sibuea@yahoo.com, ${ }^{3}$ syarifuddin.bio@gmail.com
}

\begin{abstract}
Abstrak: Penelitian ini bertujuan untuk mengetahuti: (1) apakah hasil belajar biologi antara siswa yang diajarkan dengan strategi pembelajaran diskoveri lebih tinggi dibandingkan strategi pembelajaran generatif, (2) apakah hasil belajar biologi siswa yang memiliki kecerdasan tinggi lebih tinggi dibandingkan dengan yang memiliki kecerdasan rendah, (3) terdapat interaksi antara strategi pembelajaran dan kecerdasan terhadap hasil belajar biologi. Populasi penelitian adalah seluruh siswa kelas XI SMA Negeri 1 Sei Suka dan SMA Negeri 1 Air Putih, sebanyak 6 kelas dengan jumlah siswa sebanyak 214 siswa. Metode penelitian menggunakan metode eksperimen dengan desain penelitian faktorial $2 \times 2$. Teknik analisis data menggunakan ANAVA dua jalur pada taraf signifikan $\alpha=0,05$ dimana terlebih dahulu dilakukan uji persyaratan analisis data yaitu uji normalitas dengan uji Liliefors dan uji homogenitas varians dengan uji F. Dari hasil penelitian ditemukan bahwa: (1) hasil belajar biologi siswa yang memiliki kecerdasan tinggi yang diajarkan dengan strategi pembelajaran diskoveri lebih tinggi dari strategi pembelajaran generatif dengan $\mathrm{F}_{\text {hitung }}=16,02>\mathrm{F}_{\text {tabel }}$ 3,96 (2) hasil belajar biologi siswa yang memiliki kecerdasan rendah yang diajarkan dengan strategi generatif lebih tinggi dari strategi pembelajaran diskoveri dengan $\mathrm{F}_{\text {hitung }}=$ 7,88 $>\mathrm{F}_{\text {tabel }} 3,96$ (3) terdapat interaksi antara strategi pembelajaran dan kecerdasan terhadap hasil belajar biologi dengan $\mathrm{F}_{\text {hitung }}=8,33>\mathrm{F}_{\text {tabel }} 3,96$.
\end{abstract}

Kata Kunci: strategi pembelajaran, gaya belajar, hasil belajar fisika

Abstract: This study aims to find out: (1) whether the results of biology learning between students who are taught with a diskover learning strategy is higher than generative learning strategies, (2) whether the results of biology learning students who have high intelligence are higher than those who have low intelligence, (3) there is an interaction between learning strategies and intelligence on learning outcomes of biology. The study population was all students of class XI of SMA Negeri 1 Sei Suka and SMA Negeri 1 Air Putih, as many as 6 classes with a total of 214 students. The research method uses an experimental method with a $2 \times 2$ factorial research design. The data were analyzed using two-way ANAVA at a significant level $=0.05$, where the requirements for data analysis were first tested, namely the normality test with the Liliefors test and the homogeneity test of variance by $F$ test. The results of the study found that: have high intelligence taught by the learning strategy is higher than generative learning strategies with Fcount $=16.02>$ Ftable 3.96 (2) the results of biology learning students who have low intelligence are taught with a generative strategy higher than the learning strategy covered with Fitung $=7.88>$ Ftable 3.96 (3) there is an interaction between learning strategies and intelligence on biology learning outcomes with Fcount $=8.33>$ Ftable 3.96 .

Keywords: learning strategies, learning styles, physics learning outcomes

\section{PENDAHULUAN}

Rendahnya perolehan hasil belajar biologi siswa di atas diduga karena proses pembelajaran kurang mendukung pemahaman siswa, yaitu terlalu banyak hafalan, kurang dilengkapi dengan praktek-praktek dilapangan. Strategi-strategi yang kurang mendukung tidak sesuai dengan materi yang diajarkan, mungkin terlalu monoton atau kurang bervariasi yang dapat menyebabkan hasil belajar siswa belum maksimal. Selain pemilihan strategi pembelajaran yang tepat, perolehan hasil belajar suatu kegiatan pembelajaran juga dipengaruhi oleh karakteristik siswa. Karakteristik siswa 
antara lain adalah tingkat kemandirian, kreativitas, motif berprestasi, gaya kognitif, tingkat intelegensi dan sebagainya.

Salah satu strategi yang dikembangkan dalam penelitian ini adalah strategi pembelajaran diskoveri. Menurut Burden (1999:104) pemilihan dan penerapan strategi pembelajaran diskoveri dalam mata pelajaran sains dilakukan sesuai dengan karakteristik siswa yang memerlukan kecerdasan dari siswa untuk memahami materi, menganalisis sebuah masalah dan mencari solusi pemecahan yang tepat terhadap masalah yang ditemukan, dalam kegiatan pembelajaran didalam strategi pembelajaran diskoveri dikembangkan kemampuan berpikir, pemecahan masalah dan keterampilan intelektual, serta belajar tentang berbagai peran dengan melibatkan siswa dalam pengalaman nyata atau simulasi sehingga menjadi siswa yang otonom dan mandiri

Sebagaimana telah diuraikan sehingga peneliti tertarik untuk mengadakan penelitian eksperimen terhadap permasalahan tentang penerapan strategi pembelajaran diskoveri yang diperkirakan dapat meningkatkan hasil belajar siswa pada mata pelajaran biologi. Disamping itu akan disesuaikan dengan tingkat kecerdasan siswa sebagai variabel moderator.

\section{Strategi Pembelajaran Diskoveri}

Teori belajar yang mendasari strategi pembelajaran diskoveri (penemuan) adalah teori belajar konstruktivistik. Teori belajar ini dikembangkan oleh Piaget. Menurut Piaget yang dikutip oleh Sanjaya ( 2008) mengemukakan pengetahuan itu akan bermakna manakala di cari dan ditemukan sendiri oleh siswa. Menurut Abruscato (1996:38) pembelajaran diskoveri adalah pembelajaran pengalaman yang membutuhkan pengetahuan guru yang terdiri dari pedagogi, pengembangan anak untuk menciptakan suatu lingkungan pembelajaran yang baru yang berkaitan terhadap apa terjadi sebelumnya dan apa yang akan diikuti selanjutnya. Pembelajaran melalui diskoveri merupakan pembelajaran individual yang penuh kegiatan yang ada di lingkungan yang didesain oleh seorang guru. Hal ini merupakan tanggung jawab seorang guru yang profesional untuk membantu siswa menemukan apa yang mereka sukai dan butuhkan sehingga mampu menjadikan mereka siswa yang berilmu pengetahuan, terpelajar, memiliki kecakapan, dan bertanggung jawab sebagai seorang manusia.
Menurut Barmans seperti yang dikutip oleh Abruscato (1996) ada 3 siklus penting yang membantu para guru berpikir melalui proses perencanaan dalam pembelajaran diskoveri ini tahapannya yaitu : tahap pertama eksplorasi, selama tahapan ini guru tidak berperan langsung. Guru hanya sebagai pengamat yang memiliki pertanyaan dan membantu siswa. Peranan siswa sangat aktif , dengan beberapa bahan yang diberikan oleh guru. Tahap kedua yaitu pengenalan konsep , selama pembelajaran berlangsung guru menggunakan cara biasa, guru mengumpulkan informasi dari para siswa yang berkaitan dengan pengalaman mereka, pada bagian ini buku teks, bantuan audiovisual dan tulisantulisan lain diperlukan untuk mengenalkan istilah-istilah yang akan digunakan. Tahap ketiga penerapan konsep, pada bagian ini guru membuat situasi baru atau masalah yang di selesaikan melalui pengalaman eksplorasi sebelumnya serta pengenalan konsep yang diajarkan. Pada tahap explorasi ini para siswa menggunakan beberapa aktivitas.

Menurut Burden (1999 : 104) pembelajaran diskoveri dan problem solving merupakan strategi yang digunakan untuk memecahkan masalah di bawah pengawasan guru, dalam pembelajaran diskoveri guru memimpin siswa dalam menyelesaikan masalah dan siswa menemukan apa yang telah disampaikan oleh guru. Menurut Brunner seperti yang dikutip oleh Burden (1999) pembelajaran diskoveri adalah pendekatan kognitif dimana guru menciptakan situasi yang membuat siswanya mampu belajar dengan sendirinya, siswa belajar melalui keterlibatan yang aktif dengan konsep atau dasar teori yang ada, dan mereka harus menggali keingintahuannya untuk menemukan pengalaman dan menyusun pengalaman yang mereka peroleh untuk menemukan prinsip bagi mereka sendiri, pembelajaran diskoveri memiliki beberapa keuntungan , yaitu memunculkan rasa keingintahuan siswa dan memotivasi mereka untuk menemukan jawaban. Menurut Weimer yang dikutip oleh Burden (1999) pembelajaran diskoveri akan sangat efektif ketika siswa terlibat dalam perencanaan pelajaran kemudian mereka buat penemuan, kesimpulan dan generalisasi mereka sendiri dengan bantuan guru mereka.

Hamalik (2007) mengemukakan bahwa strategi pembelajaran diskoveri adalah prosedur yang menitikberatkan studi individu, 
manipulasi objek-objek, dan eksperimen yang dilaksanakan siswa sebelum mengambil keputusan. Dalam strategi ini siswa belajar melalui partisipasi aktif menemukan konsepkonsep dan prinsip-prinsip agar mereka memperoleh pengalaman. Strategi pembelajaran diskoveri merupakan strategi yang lebih menekankan pada pengalaman langsung. Pembelajaran dengan strategi penemuan lebih mengutamakan proses dari pada hasil belajar. Strategi pembelajaran diskoveri diartikan sebagai suatu prosedur mengajar yang mementingkan pengajaran perseorangan, manipulasi objek dan lain-lain, sebelum sampai kepada generalisasi.

\section{Strategi Pembelajaran Generatif}

Strategi pembelajaran generatif ialah suatu strategi yang menekankan kepada proses pembelajaran yang dilakukan baik secara individu maupun secara berkelompok dimana masalah yang akan diteliti berasal dari siswa sendiri. Menurut Wena (2011:177) strategi pembelajaran generatif (generative learning strategy) merupakan suatu strategi pembelajaran yang menekankan pada pengintegrasian secara aktif pengetahuan baru dengan menggunakan pengetahuan yang sudah dimiliki siswa sebelumnya. Pengetahuan baru itu akan diuji dengan cara menggunakannya dalam menjawab persoalan atau gejala yang terkait. Jika pengetahuan baru itu berhasil menjawab permasalahan yang dihadapi, maka pengetahuan baru itu akan disimpan dalam memori jangka panjang, intisari dari belajar generatif adalah bahwa otak tidak menerima informasi dengan pasif, melainkan justru dengan aktif mengkonstruk suatu interpretasi dari informasi tersebut dan kemudian membuat kesimpulan. Otak bukanlah suatu blank slate yang dengan pasif belajar dan mencatat informasi yang datang.

$$
\text { Menurut Wittrock (1994) "The }
$$
generative model is a model of teaching of comprehension and the learning of the types of relations that learners must construct between stored knowledge, memories of experience, and new information for comprehension to occur. Pembelajaran generatif memiliki landasan teoritik yang berakar pada teori-teori belajar konstruktivis mengenai belajar dan pembelajaran. Butir-butir penting dari pandangan belajar menurut teori konstruktivisme ini diantaranya adalah: menekankan bahwa perubahan kognitif hanya bisa terjadi jika konsepsi-konsepsi yang telah dipahami sebelumnya diolah melalui proses ketidakseimbangan dalam upaya memahami informasi-informasi baru, seseorang dikatakan belajar jika dia bekerja dalam zona perkembangan terdekat yaitu daerah perkembangan sedikit di atas tingkat perkembangannya saat ini.

Sejumlah peneliti seperti Ogunleye dan Babajide (2011) menjelaskan bahwa para siswa telah menunjukan kemajuan yang relatif efektif dari pembelajaran generatif yang mereka terima terutama di bidang fisika, para guru fisika dan sains dapat menerapkan strategi pembelajaan generatif dalam kegiatan belajar mengajar untuk meningkatan kemampuan siswa, para siswa dapat menjelaskan konsep serta mengembangkan ide-ide yang ada dengan bantuan guru.

Lee, Lem dan Grabowski (2009) dalam jurnal menyatakan pembelajaran generatif merupakan pembelajaran yang berpusat pada guru dan siswa yang bertujuan untuk membangun ide pemikiran siswa. Aktvitas pembelajaran generatif meningkatkan pengetahuan siswa dengan menggabungkan informasi yang baru dengan informasi yang lama.

\section{Hakikat Kecerdasan}

Dalam beberapa kasus, kecerdasan bisa termasuk kreativitas, kepribadian, watak, pengetahuan, atau kebijaksanaan. Namun, beberapa psikolog tak memasukkan hal-hal tersebut dalam kerangka definisi kecerdasan. Kecerdasan merujuk pada kemampuan atau kapasitas mental dalam berpikir, namun belum terdapat definisi yang memuaskan mengenai kecerdasan.

Kecerdasan ialah istilah umum yang digunakan untuk menjelaskan sifat pikiran yang mencakup sejumlah kemampuan, seperti kemampuan menalar, merencanakan, memecahkan masalah, berpikir abstrak, memahami gagasan, menggunakan bahasa, dan belajar. Kecerdasan erat kaitannya dengan kemampuan kognitif yang dimiliki individu. Kecerdasan dapat diukur dengan menggunakan alat psikometri yang biasa disebut sebagai tes IQ. Stenberg \& Slater (1982) mendefinisikannya sebagai tindakan atau pemikiran yang bertujuan dan adaftasi, kecerdasan juga dapat diartikan keseluruhan kemampuan individu untuk berpikir dan 
bertindak secara terarah serta mengolah dan menguasai lingkungan secara efektif.

Kecerdasan dapat dibagi dua yaitu kecerdasan umum biasa disebut sebagai faktorg maupun kecerdasan spesifik. Akan tetapi pada dasarnya kecerdasan dapat dipilah-pilah, menurut LL. Thurstone kecerdasan terbagi atas pemahaman dan kemampuan verbal, angka dan hitungan, kemampuan visual, daya ingat, penalaran, dan kecepatan perseptual .Menurut Anastasi (1997) skala Wechsler merupakan skala yang umum dipergunakan untuk mendapatkan taraf kecerdasan seseorang, skala ini membagi kecerdasan menjadi dua kelompok besar yaitu kemampuan kecerdasan verbal (VIQ) dan kemampuan kecerdasan tampilan (PIQ).

Ada beberapa faktor yang mempengaruhi tingkat kecerdasan anak berbeda yaitu : (a) faktor bawaan, jadi meskipun mereka lahir dari orang tua yang sama, faktor bawaan ini bisa berbeda karena masalah genetik dan juga fungsi otak dan fungsi syaraf; (b) masalah gizi, masalah kebiasaankebiasaan dari kecil, masalah rangsangan atau stimulasi dari lingkungan; (c) latihan-latihan atau kebiasaan-kebiasaan seorang anak dari kecil (Sadli, 1986). Sedangkan pendapat lain faktor yang mempengaruhi kecerdasan, yaitu: (1) biologis; (2) lingkungan; (3) budaya; (4) bahasa; (5) masalah etika. Salah satu uji kecerdasan yang diterima luas ialah berdasarkan pada uji psikometrik atau IQ. Pengukuran kecerdasan dilakukan dengan menggunakan tes tertulis atau tes tampilan (performance test) atau saat ini berkembang pengukuran dengan alat bantu komputer.

Intelegensi bukan kemampuan tunggal dan seragam , tetapi merupakan komposit dari berbagai fungsi. Istilah umumnya digunakan untuk mencakup gabungan kemampuankemampuan yang diperlukan untuk bertahan dan maju dalam budaya tertentu ( Anastasi, 1997), Binet mendefinisikan intelegensi terdiri atas 3 komponen yaitu ; (a) kemampuan untuk mengarahkan pikiran atau mengarahkan tindakan, (b) kemampuan untuk mengubah arah tindakan bila bila tindakan tersebut telah dilaksanakan, dan (c) kemampuan untuk mengkritik diri sendiri (autocriticism).

Sejalan dengan hal ini Arikunto, (2002:76) menyatakan tes adalah merupakan alat atau prosedur yang digunakan untuk mengetahui dan mengukur sesuatu dalam pembelajaran, dengan cara skor atau angka.
Penilaian terhadap hasil belajar bertujuan untuk mengukur sejauh mana tujuan yang sudah dicapai. Untuk mengukur belajar dapat dilakukan dengan membandingkan cara siswa berprilaku pada waktu lampau dan cara siswa berprilaku waktu sekarang dalam suasana yang sama.

Bentuk test yang umum ialah : (a) ada subtest-subtest yang berisi pertanyaanpertanyaan tentang informasi secara umum yang harus diketahui anak; (b) pertanyaan yang menyangkut hal-hal sosial yang dia harus tahu; (c) menyangkut bahasa, menyangkut ketelitian dia di dalam melihat figur-figur atau gambargambar, logika, aritmatika, kemudian matematika dan sebagainya.

Tes kecerdasan tidak sama dengan hasil belajar , menurut Furchan (2011:270) tes kecerdasan berusaha mengukur penampilan umum, sedang tes hasil belajar berusaha mengukur prestasi seseorang dalam bidangbidang tertentu, kedua macam tes tersebut berusaha mngukur kemampuan subyek dalam melihat hubungan-hubungan, pemecahan masalah, dan penerapan pengetahuan dalam berbagai konteks.

Menurut Cronbach (1990) ada beberapa macam test intelegensi : (a) Test intelegensi umum, yang bertujuan untuk memberikan gambaran yang umum mengenai taraf intelegensi umum dari seseorang, (b) Test intelegensi khusus, yang hanya memberikan keterangan tentang satu segi atau faktor yang spesifik dari intelegensi, (c) Test intelegensi diferensial yang memberikan gambaran mengenai kemampun seseorang di dalam berbagai segi atau faktor intelegensi yang memungkinkan didapatkannya profil atau gambaran segi kekuatan dan kelemahan dari berfungsinya intelegensi seseorang. Cronbach menjelaskan test intelegensi dapat digunakan untuk mengetahui perbedaan murid yang normal ataupun murid dengan keterbelakangan mental, selain itu test intelegensi digunakan untuk mendiagnosa penyebab kegagalan siswa di sekolah atau rendahnya prestasi siswa di kelas, selain itu test intelegensi juga digunakan untuk melakukan seleksi terhadap siswa jika ingin masuk pada sekolah tertentu.

Menurut Branca (1964) kecerdasan tidak sama dengan pengetahuan, pengetahuan dipengaruhi oleh kecerdasan, kecerdasan juga tidak sama dengan bakat ataupun minat, karena bakat dan minat bisa dipelajari dan dikembangkan, menurut Branca siswa yang 
cerdas mampu menguasai pelajaran dengan baik, siswa tersebut mampu mengingat apa yang telah di pelajari, mampu memecahkan masalah yang dihadapi dengan cepat dan tepat, dibandingkan dengan siswa yang tidak cerdas. Menurut Baron (2001) kecerdasan mengarah kepada seseorang yang memiliki pandangan yang cukup luas, mampu beradaptasi dengan lingkungannya, mampu belajar dari pengalaman, serta mampu memberikan penyelesaian terhadap masalah yang dihadapi.

adalah :

$$
\text { Rumusan masalah penelitian ini }
$$

1. Apakah hasil belajar biologi siswa yang diajar dengan strategi pembelajaran diskoveri lebih tinggi dari pada siswa yang diajar dengan strategi pembelajaran generatif ?

2. Apakah hasil belajar biologi siswa yang mempunyai kecerdasan tinggi lebih tinggi dari pada siswa yang mempunyai kecerdasan rendah?

3. Apakah ada interaksi antara strategi pembelajaran dan kecerdasan terhadap hasil belajar biologi siswa?

\section{METODE}

Penelitian dilaksanakan di Sekolah Menengah Atas (SMA) Negeri 1 Sei Suka dan SMA Negeri 1 Air Putih di Kab. Batu bara . Pelaksanaan penelitian ini dilaksanakan dalam 8 (delapan) pertemuan pada siswa kelas XI. Populasi dalam penelitian ini adalah siswa SMA Negeri 1 Sei Suka yaitu sebanyak 3 (tiga) kelas yang terdiri dari XI-IPA 1 sampai kelas XI-IPA 3 dengan jumlah 102 siswa dan siswa SMA Negeri 1 Air Putih yaitu sebanyak 3 (tiga) kelas dari XI-IPA 1 sampai kelas XI-IPA 3 dengan jumlah 112 siswa. Di antara kelas ini tidak terdapat kelas unggulan dimana setiap kelas memiliki karakteristik yang sama, artinya setiap kelas tidak memiliki siswa yang pernah tinggal kelas, siswa rata-rata memiliki umur yang tidak jauh berbeda, dan menggunakan kurikulum yang sama.

Penelitian ini menggunakan metode kuasi eksperimen dengan rancangan eksperimen disain faktorial $2 \times 2$. Melalui rancangan ini akan dibandingkan pengaruh strategi pembelajaran diskoveri dan strategi pembelajaran generatif terhadap hasil belajar biologi ditinjau dari siswa yang memiliki kecerdasan tinggi dan rendah. Strategi pembelajaran diskoveri dan strategi pembelajaran generatif sebagai variabel bebas.
Kecerdasan tinggi dan rendah sebagai variabel moderator dan perolehan hasil belajar dalam mata pelajaran biologi sebagai variabel terikat. Variabel-variabel tersebut selanjutnya akan dimasukkan di dalam rancangan penelitian pada Tabel 1 sebagai berikut:

Tabel 1. Rancangan Penelitian Untuk Pengujian Hipotesis

\begin{tabular}{lcc}
$\begin{array}{c}\text { Kecerdasan } \\
(\mathbf{B})\end{array}$ & \multicolumn{2}{c}{ Strategi Pembelajaran (A) } \\
\cline { 2 - 3 } Tinggi (B1) & Diskoveri (A1) & Generatif (A2) \\
\hline Rendah (B2) & $\mathrm{A}_{1} \mathrm{~B}_{1}$ & $\mathbf{A}_{\mathbf{2}} \mathbf{B}_{1}$ \\
\hline
\end{tabular}

Keterangan :

$\mathrm{A}_{1} \mathrm{~B}_{1}=$ Hasil belajar biologi siswa kelompok siswa yang memiliki kecerdasan tinggi yang menggunakan strategi pembelajaran diskoveri

$\mathrm{A}_{1} \mathrm{~B}_{2}=$ Hasil belajar biologi siswa kelompok siswa yang memiliki kecerdasan rendah yang menggunakan strategi pembelajaran diskoveri

$\mathrm{A}_{2} \mathrm{~B}_{1}=$ Hasil belajar biologi siswa kelompok siswa yang memiliki kecerdasan tinggi yang menggunakan strategi pembelajaran generatif

$\mathrm{A}_{2} \mathrm{~B}_{2}=$ Hasil belajar biologi siswa kelompok siswa yang memiliki kecerdasan rendah yang menggunakan strategi pembelajaran generatif

Untuk menguji hipotesis penelitian digunakan teknik analisis data dengan analisis varians (Anava) dua jalur dengan taraf signifikan 0,05 (Sudjana, 1994). Untuk menggunakan Anava dua jalur perlu dipenuhi beberapa syarat yaitu: (1) data yang digunakan harus berdistribusi normal, maka dilakukan uji normalitas dengan menggunakan Uji Liliefors; (2) data harus memiliki varians populasi yang homogen maka dilakukan uji homogenitas varians dengan menggunakan Uji Bartlett dan Uji Fisher (Sudjana, 1984). Melakukan pengujian dengan persyaratan analisis, selanjutnya dilakukan pengujian Anava 2 jalur. Jika Anava 2 jalur signifikan, maka diadakan uji lanjut (post hoc test) jika jumlah sampel tiap sel tidak sama (n tidak sama), maka akan digunakan uji Schefee'

Adapun hipotesis statistik yang akan diuji adalah:

1. Hipotesis Pertama

$\mathrm{H}_{\mathrm{o}}: \mu \mathrm{A}_{1} \leq \mu \mathrm{A}_{2}$

$\mathrm{H}_{\mathrm{a}}: \mu \mathrm{A}_{2}>\mu \mathrm{A}_{2}$

2. Hipotesis Kedua 

$\mathrm{H}_{\mathrm{o}}: \mu \mathrm{B}_{1} \leq \mu \mathrm{B}_{2}$
$\mathrm{H}_{\mathrm{a}}: \mu \mathrm{B}_{1}>\mu \mathrm{B}_{2}$

3. Hipotesis Ketiga
$\mathrm{H}_{\mathrm{o}}: \mathrm{A} \times \mathrm{B}=0$
$\mathrm{H}_{\mathrm{a}}: \mathrm{A} \times \mathrm{B} \neq 0$

\section{Keterangan :}

$\mu \mathrm{A}_{1}=$ rata-rata nilai hasil belajar biologi siswa yang diajarkan dengan Strategi Pembelajaran Diskoveri

$\mu \mathrm{A}_{2}=$ rata-rata nilai hasil belajar biologi siswa yang diajarkan dengan Strategi Pembelajaran Generatif

$\mu \mathrm{B}_{1}=$ rata-rata nilai hasil belajar biologi siswa yang memiliki kecerdasan tinggi $\mu \mathrm{B}_{2}=$ rata-rata nilai hasil belajar biologi siswa yang memiliki kecerdasan rendah.

A $x$ B $=$ interaksi antara Strategi Pembelajaran dengan Kecerdasan siswa

\section{HASIL PENELITIAN}

Berdasarkan data skor tes hasil belajar Biologi siswa, langkah berikutnya adalah menghitung total skor dan rata-rata skor tiap kelompok perlakuan menurut tabel anava, yang selanjutnya dapat digunakan sebagai dasar keputusan statistik untuk pengujian hipotesis, seperti pada Tabel 2 sebagai berikut :

Tabel 2. Rangkuman Data Hasil Penelitian

\begin{tabular}{ccccc}
\hline Kecerdasan (B) & Ket & \multicolumn{2}{c}{ Strategi Pembelajaran $(A)$} & Total \\
\cline { 2 - 4 } & & Diskoveri $\left(\mathrm{A}_{1}\right)$ & Generatif $\left(\mathrm{A}_{2}\right)$ & \\
\hline $\begin{array}{c}\text { Tinggi } \\
\left(\mathbf{B}_{1}\right)\end{array}$ & $\mathrm{N}$ & 23 & 22 & 45 \\
\cline { 2 - 4 } & $\bar{X}$ & 36,17 & 32,77 & 34,47 \\
\cline { 2 - 4 } $\begin{array}{c}\text { Rendah } \\
\left(\mathbf{B}_{2}\right)\end{array}$ & $\mathrm{SD}$ & 2,315 & 2,411 & \\
\cline { 2 - 4 } & $\overline{\mathrm{N}}$ & 18 & 14 & 32 \\
\hline Total & $\mathrm{SD}$ & 2,636 & 32,71 & 23,97 \\
\hline & $\overline{\mathrm{N}}$ & 41 & 1,708 & \\
\hline & $\bar{X}$ & 34,70 & 36 & 77 \\
\hline
\end{tabular}
bawah ini.

Secara keseluruhan hasil Anava untuk pengujian hipotesis dapat dilihat pada Tabel 3 di

Tabel 3. Rangkuman Hasil Anava Secara Keseluruhan Terhadap Hasil Belajar Biologi

\begin{tabular}{|c|c|c|c|c|c|c|}
\hline Sumber Variasi & JK & dk & KT & $F_{\text {hitung }}$ & $\mathrm{F}_{\text {tabel }} \mathbf{5 \%}$ & $\begin{array}{c}F_{\text {tabel }} \\
1 \%\end{array}$ \\
\hline $\begin{array}{l}\text { Strategi } \\
\text { Pembelajaran }\end{array}$ & 86,808 & 1 & 86,808 & 16,02 & 3,96 & 7,01 \\
\hline Kecerdasan & 42,704 & 1 & 42,704 & 7,88 & 3,96 & \\
\hline Interaksi & 45,303 & 1 & 45,303 & 8,36 & 3,96 & \\
\hline Galat & 417,136 & 73 & 5,417 & & & \\
\hline Jumlah & 591,951 & 76 & & & & \\
\hline
\end{tabular}

Karena $\mathrm{F}_{\text {hitung }}>\mathrm{F}_{\text {tabel }} 3,96$, dapat disimpulkan adanya interaksi antara strategi pembelajaran dengan kecerdasan dalam mempengaruhi hasil belajar biologi siswa.

Perbedaan Hasil Belajar Biologi Antara Siswa Yang Memperoleh Strategi Pembelajaran Diskoveri dan Generatif

Adapun hipotesis statistik yang diuji adalah

Ho : $\mu \mathrm{A} 1=\mu \mathrm{A} 2$

$\mathrm{Ha}: \mu \mathrm{A} 1>\mu \mathrm{A} 2$

Pernyataan hipotesis tersebut ialah :
$\mathrm{H}_{\mathrm{o}}$ : Hasil belajar biologi siswa yang diajar dengan Strategi Pembelajaran Diskoveri sama dengan hasil belajar biologi siswa yang diajar strategi Pembelajaran Generatif

$\mathrm{H}_{\mathrm{o}}$ : Hasil belajar biologi siswa yang diajar dengan strategi Pembelajaran Diskoveri lebih tinggi dari pada hasil belajar biologi siswa yang diajar Strategi Pembelajaran Generatif 
Berdasarkan hasil pengujian hipotesis diperoleh $\bar{X}=34,70$ untuk hasil belajar biologi siswa untuk Strategi Pembelajaran Diskoveri. Sedangkan hasil belajar biologi siswa untuk Strategi Pembelajaran Generatif $\bar{X}=33,74$, didapat perhitungan $\mathrm{F}_{\text {hitung }} 16,02$ dan $\mathrm{F}_{\text {tabel }} 3,96$ dengan $\alpha=0,05$ serta $F_{\text {tabel }} 7,01$ dengan $\alpha=0,01$. Hasil ini menunjukkan bahwa $F_{\text {hitung }}=16,02>$ $F_{\text {tabel }}=3,96$ sehingga Hipotesis Nol (Ho) ditolak, dengan demikian hipotesis penelitian yang menyatakan bahwa hasil belajar biologi siswa yang diajar dengan Strategi Pembelajaran Diskoveri lebih tinggi dari pada siswa yang diajarkan dengan strategi Pembelajaran Generatif teruji kebenarannya.

\section{Perbedaan Hasil Belajar Biologi Antara Siswa Yang Memiliki Kecerdasan Tinggi Dan Rendah.}

Adapun hipotesis statistik yang diuji adalah :

Ho : $\mu \mathrm{B} 1=\mu \mathrm{B} 2$

$\mathrm{Ha}: \mu \mathrm{B} 1>\mu \mathrm{B} 2$

Pernyataan hipotesis tersebut ialah :

$\mathrm{H}_{\mathrm{o}}$ : Hasil belajar biologi siswa yang memiliki kecerdasan tinggi sama dengan hasil belajar biologi siswa yang memiliki kecerdasan rendah

$\mathrm{H}_{\mathrm{o}}$ : Hasil belajar biologi siswa yang memiliki kecerdasan tinggi lebih tinggi dari pada hasil belajar biologi siswa yang memiliki kecerdasan rendah

Berdasarkan hasil pengujian hipotesis diperoleh $\bar{X}=34,47$ untuk hasil belajar biologi siswa yang memiliki kecerdasan tinggi. Sedangkan hasil belajar biologi siswa yang memiliki kecerdasan rendah $\bar{X}=23,97$, didapat perhitungan $F_{\text {hitung }} 7,88$ dan $F_{\text {tabel }} 3,96$ dengan $\alpha$ $=0,05$ serta $F_{\text {tabel }} 7,01$ dengan $\alpha=0,01$. Hasil ini menunjukkan bahwa $\mathrm{F}_{\text {hitung }}=7,88>\mathrm{F}_{\text {tabel }}=3,96$ sehingga Hipotesis Nol (Ho) ditolak, dengan demikian hipotesis penelitian yang menyatakan bahwa hasil belajar biologi siswa yang memiliki kecerdasan tinggi lebih tinggi dari pada siswa yang memiliki kecerdasan rendah teruji kebenarannya.

\section{Interaksi Antara Strategi Pembelajaran dan Kecerdasan Siswa Dalam Mempengaruhi Hasil Belajar Biologi}

Adapun hipotesis statistik yang diuji adalah :

Ho: $\mathrm{A} \times \mathrm{B}=0$

$\mathrm{Ha}: \mathrm{A} \times \mathrm{B} \neq 0$

Pernyataan hipotesis terbut ialah :

$\mathrm{H}_{\mathrm{o}}$ : Tidak terdapat interaksi antara strategi pembelajaran dan kecerdasan terhadap hasil belajar biologi siswa

$\mathrm{H}_{\mathrm{o}}$ : Terdapat interaksi anatra strategi pembelajaran dan kecerdasan terhadap hasil belajar biologi siswa

Berdasarkan hasil pengujian hipotesis diperoleh $\mathrm{F}_{\text {hitung }} 8,36$ dan $\mathrm{F}_{\text {tabel }} 3,96$ dengan $\alpha=$ 0,05 serta $F_{\text {tabel }} 7,01$ dengan $\alpha=0,01$. Hasil ini menunjukkan bahwa $\mathrm{F}_{\text {hitung }}=8,36>\mathrm{F}_{\text {tabel }}=3,96$ sehingga Hipotesis Nol (Ho) ditolak, dengan demikian hipotesis penelitian yang menyatakan bahwa terdapat interaksi antara strategi pembelajaran dan kecerdasan terhadap hasil belajar biologi siswa telah teruji kebenarannya.

Karena ada interaksi antara strategi pembelajaran dan kecerdasan mempengaruhi hasil belajar biologi siswa, maka perlu dilakukan uji lanjutan (post hoc test), untuk mengetahui rata-rata hasil belajar sampel mana yang berbeda. Untuk melihat bentuk interaksi antara strategi pembelajaran dan kecerdasan dalam mempengaruhi hasil belajar biologi siswa, dilakukan uji lanjut dengan menggunakan uji Scheffe'. Rangkuman hasil uji Scheffe' dapat dilihat pada Tabel 4 berikut:

Tabel 4. Rangkuman Hasil Perhitungan Uji Scheffe'

\begin{tabular}{|c|c|c|c|}
\hline \multicolumn{2}{|c|}{ HIPOTESIS STATISTIK } & $\mathbf{F}_{\text {hitung }}$ & $\mathbf{F}_{\text {Tabel }} \boldsymbol{\alpha}=\mathbf{0 , 0 5}$ \\
\hline Ho: $\mu A_{1} B_{1}=\mu A_{2} B_{1}$ & Ha: $\mu A_{1} B_{1}>\mu A_{2} B_{1}$ & 7,060 & 3,96 \\
\hline Ho: $\mu A_{1} B_{1}=\mu A_{1} B_{2}$ & Ha: $\mu A_{1} B_{1}>\mu A_{1} B_{2}$ & 5,326 & \\
\hline Ho: $\mu A_{1} B_{1}=\mu A_{2} B_{2}$ & Ha: $\mu A_{1} B_{1}>\mu A_{2} B_{2}$ & 6,448 & \\
\hline Ho: $\mu A_{1} B_{2}=\mu A_{2} B_{1}$ & Ha: $\mu A_{1} B_{2}<\mu A_{2} B_{1}$ & 0,796 & \\
\hline Ho: $\mu A_{1} B_{2}=\mu A_{2} B_{2}$ & $\mathrm{Ha}: \mu \mathrm{A}_{1} \mathrm{~B}_{2}<\mu \mathrm{A}_{2} \mathrm{~B}_{2}$ & 0,820 & \\
\hline Ho: $\mu A_{2} B_{1}=\mu A_{2} B_{2}$ & Ha: $\mu A_{2} B_{1}<\mu A_{2} B_{2}$ & 0,107 & \\
\hline
\end{tabular}


Berdasarkan hasil uji Scheffe' pada Tabel 4 di atas dapat diperoleh kesimpulan yakni:

a. Rata-rata hasil belajar biologi siswa jika diajar menggunakan Strategi Pembelajaran Diskoveri yang memiliki kecerdasan tinggi dibandingkan dengan Strategi Pembelajaran generatif yang memiliki kecerdasan kecerdasan tinggi menghasilkan $\mathrm{F}_{\text {hitung }}$ sebesar 7,060 dibanding dengan nilai $\mathrm{F}_{\text {tabel }}$ sebesar 3,96 dengan demikian $\mathrm{F}_{\text {hitung }}=7,060$ $>\mathrm{F}_{\text {tabel }}$ 3,96. Ini berarti terdapat perbedaan hasil belajar biologi siswa yang diajar dengan Strategi Pembelajaran Diskoveri yang memiliki kecerdasan tinggi dengan siswa yang diajar dengan Strategi Pembelajaran Generatif yang memiliki kecerdasan tinggi.

b. Rata-rata hasil belajar biologi siswa jika diajar menggunakan Strategi Pembelajaran Diskoveri yang memiliki kecerdasan tinggi dibandingkan dengan Strategi Pembelajaran Diskoveri yang memiliki kecerdasan kecerdasan rendah menghasilkan $F_{\text {hitung }}$ sebesar 5,326 dibanding dengan nilai $\mathrm{F}_{\text {tabel }}$ sebesar 3,96 dengan demikian $\mathrm{F}_{\text {hitung }}=5,326$ $>\mathrm{F}_{\text {tabel }}$ 3,96. Ini berarti terdapat perbedaan hasil belajar biologi siswa yang diajar dengan Strategi Pembelajaran Diskoveri yang memiliki kecerdasan tinggi dengan siswa yang diajar dengan strategi Pembelajaran Diskoveri yang memiliki kecerdasan rendah.

c. Rata-rata hasil belajar biologi siswa jika diajar dengan Strategi Pembelajaran Diskoveri yang memiliki kecerdasan tinggi dibandingkan dengan Strategi Pembelajaran generatif yang memiliki kecerdasan kecerdasan rendah menghasilkan $F_{\text {hitung }}$ sebesar 6,448 dibanding dengan nilai $\mathrm{F}_{\text {tabel }}$ sebesar 3,96 dengan demikian $\mathrm{F}_{\text {hitung }}=4,582$ $>\mathrm{F}_{\text {tabel }}$ 3,96. Ini berarti ada perbedaan hasil belajar biologi siswa yang diajar dengan Strategi Pembelajaran Diskoveri yang memiliki kecerdasan tinggi dengan siswa yang diajar dengan Strategi Pembelajaran generatif yang memiliki kecerdasan rendah.

d. Rata-rata hasil belajar biologi siswa jika diajar menggunakan Strategi Pembelajaran Diskoveri yang memiliki kecerdasan rendah dibandingkan dengan Strategi Pembelajaran Generatif yang memiliki kecerdasan kecerdasan tinggi menghasilkan $F_{\text {hitung }}$ sebesar 0,796 dibanding dengan nilai $\mathrm{F}_{\text {tabel }}$ sebesar 3,96 dengan demikian $\mathrm{F}_{\text {hitung }}=0,796$
$<\mathrm{F}_{\text {tabel }}$ 3,96. Ini berarti tidak terdapat perbedaan hasil belajar biologi siswa yang diajar dengan Strategi Pembelajaran Diskoveri yang memiliki kecerdasan rendah dengan siswa yang diajar dengan strategi Pembelajaran Generatif yang memiliki kecerdasan tinggi.

e. Rata-rata hasil belajar biologi siswa jika diajar menggunakan Strategi Pembelajaran Diskoveri yang memiliki kecerdasan rendah dibandingkan dengan Strategi Pembelajaran Generatif yang memiliki kecerdasan kecerdasan rendah menghasilkan $F_{\text {hitung }}$ sebesar 0,820 dibanding dengan nilai $\mathrm{F}_{\text {tabel }}$ sebesar 3,96 dengan demikian $\mathrm{F}_{\text {hitung }}=0,820$ $<\mathrm{F}_{\text {tabel }}$ 3,96. Ini berarti tidak terdapat perbedaan hasil belajar biologi siswa yang diajar dengan Strategi Pembelajaran Diskoveri yang memiliki kecerdasan rendah dengan siswa yang diajar dengan Strategi Pembelajaran Generatif yang memiliki kecerdasan rendah.

f. Rata-rata hasil belajar biologi siswa jika diajar menggunakan Strategi Pembelajaran Generatif yang memiliki kecerdasan tinggi dibandingkan dengan Strategi Pembelajaran Generatif yang memiliki kecerdasan kecerdasan rendah menghasilkan $\mathrm{F}_{\text {hitung }}$ sebesar 0,107 dibanding dengan nilai $\mathrm{F}_{\text {tabel }}$ sebesar 3,96 dengan demikian $\mathrm{F}_{\text {hitung }}=0,107$ $<\mathrm{F}_{\text {tabel }}$ 3,96. Ini berarti tidak terdapat perbedaan hasil belajar biologi siswa yang diajar dengan Strategi Pembelajaran Generatif yang memiliki kecerdasan tinggi dengan siswa yang diajar dengan Strategi Pembelajaran Generatif yang memiliki kecerdasan rendah.

Selanjutnya, adanya interaksi antara variabel strategi pembelajaran dan kecerdasan terhadap hasil belajar biologi siswa, maka dapat divisualisasikan dalam bentuk grafis pada Gambar 1.

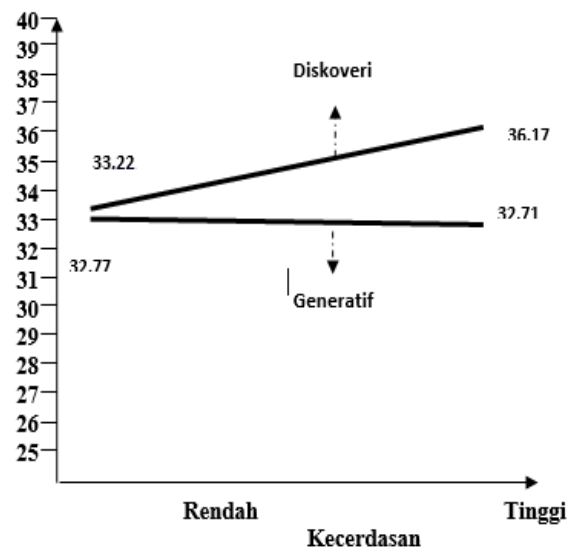


PEMBAHASAN

Perbedaan hasil belajar Biologi siswa yang diajar dengan Strategi Pembelajaran Diskoveri dibandingkan dengan siswa yang diajar dengan Strategi Pembelajaran Generatif

Hasil penelitian ini telah menunjukkan bahwa hasil belajar biologi siswa yang diajar dengan Strategi Pembelajaran Diskoveri lebih tinggi dibandingkan dengan Strategi Pembelajaran Generatif. Biologi merupakan mata pelajaran yang sangat penting agar siswa memiliki kemampuan memahami mengamati, mendeskripsikan, dan menganalisis gejalagejala alam sehingga menjadi struktur pengetahuan yang bersistem. Sesuai tujuan dapat dipahami bahwa pelajaran biologi memiliki cakupan yang sangat luas, sehingga proses pembelajaran harus memberikan kesempatan kepada siswa untuk menganalisis dan memamahi materi pelajaran secara kritis, analitis agar nilai-nilai yang terkandung dalam mata pelajaran biologi dapat dipahami dan diyakini oleh siswa. Untuk itu, guru diharapkan memiliki pengetahuan dan pemahaman mengenai strategi pembelajaran, sebab pengetahuan dan pemahaman mengenai strategi pembelajaran sangat penting sebagai salah satu upaya dalam memberikan pengalaman dan pencapaian tujuan belajar yang optimal. Guru dituntut untuk meningkatkan kualitas pembelajaran dan harus memperhatikan hakikat, tujuan mata pelajaran yang akan diajarkan, serta mempertimbangkan karakteristik siswa. Artinya, penguasaan guru terhadap strategi pembelajaran sangat diperlukan untuk meningkatkan kemampuan profesional guru dalam mengajar, oleh sebab itu guru harus dapat menentukan strategi yang paling tepat dan sesuai dengan tujuan serta materi yang akan disampaikannya.

Pembelajaran melalui diskoveri merupakan pembelajaran individual yang penuh kegiatan yang ada di lingkungan yang didesain oleh seorang guru. Hal ini merupakan tanggung jawab seorang guru yang profesional untuk membantu siswa menemukan apa yang mereka sukai dan butuhkan sehingga mampu menjadikan mereka siswa yang berilmu pengetahuan, terpelajar, memiliki kecakapan, dan bertanggung jawab sebagai seorang manusia, pembelajaran diskoveri adalah pendekatan kognitif dimana guru menciptakan situasi yang membuat siswanya mampu belajar dengan sendirinya, siswa belajar melalui keterlibatan yang aktif dengan konsep atau dasar teori yang ada, dan mereka harus menggali keingintahuannya untuk menemukan pengalaman dan menyusun pengalaman yang mereka peroleh untuk menemukan prinsip bagi mereka sendiri, pembelajaran diskoveri memiliki beberapa keuntungan, yaitu memunculkan rasa keingintahuan siswa dan memotivasi mereka untuk menemukan jawaban.

Strategi Pembelajaran Generatif merupakan suatu strategi pembelajaran yang menekankan pada pengintegrasian secara aktif pengetahuan baru dengan menggunakan pengetahuan yang sudah dimiliki siswa sebelumnya. Jika pengetahuan baru itu berhasil menjawab permasalahan yang dihadapi, maka pengetahuan baru itu akan disimpan dalam memori jangka panjang. Strategi pembelajaran ini dengan meningkatkan pengetahuan, kemampuan konsep yang dipelajari untuk mengkonstruksi/membangun pengetahuan baru secara mandiri dari pengalaman dan situasi kehidupan sehari-hari sehingga mudah untuk diterapkan di dalam situasi kelas. Dengan melakukan langkah-langkah tersebut, memungkinkan siswa untuk lebih berinteraksi dan mengekplorasi pengetahuan yang ada dalam dirinya untuk mengembangkan ide pemikirannya untuk memecahkan masalah.

Masalah yang ditemukan sendiri oleh siswa menjadikan pembelajaran lebih menjadikan siswa untuk mudah mengkonstruk/membangun pengetahuan barunya pada kondisi nyata untuk dipecahkan masalahnya secara bersama-sama. Selain pembelajaran dilakukan secara individu juga melibatkan kelompok sehingga interaksi akan membantu dalam memudahkan pemecahan masalah yang ada. Dengan demikian pengalaman sehari-hari akan dihubungkan dengan yang lain sehingga nantinya dalam penerapan konsep sesuai dengan konsep, prinsip dalam materi pembelajaran. Latihanlatihan soal diakhir pembelajaran juga akan memberikan peningkatan memori jangka panjang di dalam otak untuk bisa menerapakan konsep dan prinsip-prinsip dalam memecahkan soal yang ada. Dengan demikian penerapan model pembelajaran ini akan lebih optimal di dalam kelas sesuai stándar kompetensi dan kompetensi dasar melalui pencapaian indikatorindikator pada materi pembelajaran biologi karena masalah tersebut ada disekitar siswa dan sekolah. 
Dari uraian di atas, dapat dipahami bahwa hasil belajar biologi siswa yang diajar dengan Strategi Pembelajaran Diskoveri lebih tinggi dari pada siswa yang dibelajarkan dengan Strategi Pembelajaran generatif.

\section{Perbedaan Hasil Belajar Biologi Siswa antara yang memiliki Kecerdasan Tinggi dengan Kecerdasan Rendah}

Hasil penelitian ini telah menunjukkan bahwa siswa yang memiliki kecerdasan tinggi memperoleh nilai rata-rata hasil belajar biologi yang lebih tinggi dibandingkan dengan siswa yang memiliki kecerdasan rendah. Hal ini berindikasi bahwa siswa yang mempunyai kecerdasan tinggi lebih mampu memahami dan memecahkan masalah yang ada disekelilingnya sebagai bagian dari materi mata pelajaran biologi dibandingkan dengan siswa yang memiliki kecerdasan rendah.

Siswa yang memiliki kecerdasan tinggi akan lebih mudah dalam mengintegrasikan pengetahuan yang lama dengan yang baru dalam mempelajari biologi terkait materi yang dibahas. Dengan segala kemampuan yang dimiliki ini siswa yang memiliki kecerdasan tinggi akan lebih mudah mencapai kompetensi dasar dan indikator dalam mata pelajaran biologi dari pada siswa yang memiliki kecerdasan rendah. Hal ini memungkinkan siswa yang memiliki kecerdasan tinggi memperoleh hasil belajar yang lebih baik pula.

Pada penelitian ini juga dapat dibuktikan bahwa kecerdasan mampu meningkatkan kompetensi siswa dalam mata pelajaran biologi. Pada siswa yang memiliki kecerdasan rendah mengalami kesulisan dalam memahami materi pelajaran yang disajikan karena keterlabatan dalam daya nalar yang dimiliki siswa. Karena siswa yang memiliki kecerdasan rendah, memiliki memori jangka pendek dan lambat untuk berfikir kritis terhadap masalah yang dihadapinya. Secara struktural, materi ini menuntut siswa agar mempunyai penalaran yang tinggi sehingga pencapaian kompetensi yang ingin dicapai akan mengalami kesulitan/keterlambatan dalam memahaminya. Oleh karena itu dibutuhkan strategi pembelajaran khusus untuk menerapkannya bagi siswa yang memiliki kecerdasan rendah. Selain itu, siswa yang memiliki kecerdasan rendah akan sulit untuk mengembangkan diri dalam belajar karena satu arah antara guru dan siswa.
Materi pelajaran biologi yang begitu kompleks memberikan tantangan bagi siswa untuk meningkatkan daya nalarnya, namun siswa yang memiliki kecerdasan rendah membutuhkan waktu yang relatif lama untuk dapat memecahkan masalah yang dihadapinya. Dengan demikian, akan mengalami ketertinggalan berfikir dibandingkan dengan siswa yang memiliki kecerdasan tinggi. Sturktur otak yang lambat, menjadi kendala, sehingga dibutuhkan suatu upaya tertentu untuk mengoptimalkan kecerdasan tersebut dengan menerapkan suatu strategi pembelajaran yang sesuai pada siswa untuk belajar di dalam kelas. Strategi pembelajaran yang sesuai merupakan model yang membutuhkan langkah-langkah yang lebih detail dalam tahapannya sehingga akan dapat merangsang otak siswa untuk meningkatkan daya nalarnya dalam pemecahan masalah materi pembelajaran.

Berdasarkan uraian di atas, dapat dipahami bahwa siswa yang mempunyai kecerdasan tinggi memperoleh hasil belajar biologi siswa yang lebih tinggi dibandingkan dengan siswa yag mempunyai kecerdasan rendah.

\section{Interaksi antara Strategi Pembelajaran dan Kecerdasan dalam Mempengaruhi Hasil Belajar Biologi Siswa}

Hasil penelitian ini telah menunjukkan bahwa terdapat interaksi antara Strategi Pembelajaran dan kecerdasan dalam mempengaruhi hasil belajar biologi siswa. Siswa yang memiliki kecerdasan tinggi yang diajar Strategi Pembelajaran Diskoveri lebih tinggi hasil belajarnya dibandingkan dengan siswa yang memiliki kecerdasan rendah. Demikian pula siswa yang memiliki kecerdasan rendah dengan menerapkan Strategi Pembelajaran Generatif yang memperoleh hasil belajar lebih tinggi, dibandingkan dengan siswa yang memiliki kecerdasan tinggi yang diajar dengan Strategi Pembelajaran Generatif. Hal ini mengindikasikan adanya interaksi antara penerapan strategi pembelajaran dan kecerdasan terhadap hasil belajar biologi siswa.

Mata pelajaran biologi merupakan mata pelajaran yang menuntut kompetensi dasar siswa untuk dapat berfikir mengandalkan proses penalaran dari masalah yang muncul yang ada disekelilingnya. Proses penalaran kritis inilah yang semestinya diterapkan dalam pembelajaran biologi agar siswa merasa dilibatkan secara aktif untuk memperoleh 
informasi biologi disamping sumber lainnya. Kemampuan ini akan lebih mudah diperoleh siswa yang memiliki kecerdasan tinggi dalam proses penalaran yang dilakukan. Siswa yang memiliki kecerdasan tinggi akan cendrung dapat memahami objek di lingkungan yang dialami. Sikap ini akan berkembang jika siswa berlangsung dalam menerapkan kegiatankegiatan pembelajaran sesuai petunjuk dari Strategi Pembelajaran Diskoveri. Oleh karena itu dengan penerapakan Strategi Pembelajaran Diskoveri akan memberikan hasil belajar biologi siswa yang lebih tinggi.

Untuk siswa yang memiliki kecerdasan rendah, maka hasil belajar biologi siswa lebih baik jika diterapkan Strategi Pembelajaran generatif dari pada diterapkan Strategi Pembelajaran Diskoveri.

\section{PENUTUP}

1. Hasil belajar Biologi siswa SMA Negeri Kabupaten Batubara yang diajar dengan Strategi Pembelajaran Diskoveri lebih tinggi jika dibandingkan dengan yang diajar menggunakan Strategi Pembelajaran Generatif.

2. Siswa yang memiliki kecerdasan tinggi memperoleh hasil belajar biologi yang lebih tinggi dibandingkan dengan siswa yang memiliki kecerdasan rendah.

3. Terdapat interaksi antara strategi pembelajaran dan kecerdasan dalam mempengaruhi hasil belajar biologi siswa SMA Negeri Kabupaten Batubara. Untuk siswa yang memiliki kecerdasan tinggi akan lebih efektif dalam meningkatkan hasil belajar biologi siswa jika diajar dengan Strategi Pembelajaran Diskoveri, sedangkan untuk siswa yang memiliki kecerdasan rendah, ternyata Strategi Pembelajaran Generatif lebih efektif dalam meningkatkan hasil belajar biologi siswa dibandingkan jika menggunakan Strategi Pembelajaran Diskoveri

\section{DAFTAR PUSTAKA}

Abruscato, Joseph, (1996) Teaching Children Science A Discovery Approach, University of Vermont

Anastasi, Anne (1997) Tes Psikologi . Jakarta : Prenhallindo. Terjemahan

Arikunto, (2002). Dasar-dasar Evaluasi pendidikan. Jakarta: Bumi Aksara.

Atmodiwirio, Soebagio. (2002) Manajemen Pelatihan . Jakarta: Ardadizya Jaya
Baron, A Robert. (2001) Psychology $5^{\text {th }}$ editon, Alyn and bacon. Prentice Hall of India

Bruner,J (1986) Introduction The New Educational Technology, Cambridge, Mass: Harvard University Press

Burden, Paul R. (1999). Methods for Effective Teaching, Alyn and bacon. Library of Congress Cataloging in Publication Data

Branca, A, Albert (1964) Psychology, Allyn and Bacon Publisher

Campbell NA, Reece JB. (2009). Biology, USA. Pearson Benjamin Cummings

Carin, Arthur A, and Robert B. Sund (1980) Teaching Science Through Discovery, Merril Publishing Co.

Cronbach, L.J., (1990) Essentials of Psychological Testing, Harper International Edition, New York, Harper Collins Publisher

Dahar, W. Wilis , (1991) Teori-Teori Belajar, Bandung : Gelora Akasara Pratama

Darmayanti, Nefi (2001) Buku panduan Tes Intelegensi, Medan : Universitas Medan Area.

Dick and Carey (2005) The systematic Design of Instruction. London: Scott, Foresman and Company.

Furchan, Arief. (2011) . Pengantar Penelitian Dalam Pendidikan. Yogyakarta : Pustaka Pelajar

Gagne, R. (1965). Principles of Instructional Design. New York: Holt, Rinehart \& Wiston.

Gall, Meredith, Joyce and Burg (2003) Educational Research :An Introduction . Pearson Education Inc.

Gronlund, E. Norman. (1985) Measurement and Evaluation in Teaching, $5^{\text {th }}$ Edition New York : Macmillan Publishing

Grabowski. L. Barbara. (2001) Generative Learning Contributions to The Design of Instruction and Learning. Pennsylvania State University

Hamalik, Oemar. (2007) Dasar-Dasar Pengembangan Kurikulum . Bandung Remaja Rosdakarya

Hasibuan. (2010). Pengaruh Strategi Pembelajaran dan Gaya Berpikir Terhadap Hasil Belajar Biologi. Tesis Program Pasca Sarjana Unimed. Tesis tidak diterbitkan.

Hurlock, B. Elizabeth. (1980) Psikologi Perkembangan. Jakarta : Penerbit Erlangga 
Lee, Lem \& Grabowski. (2008) Generative Learning Principle and Implicationsfor Making Meaning. Pennsylvania State University. Handbook of Research on Educational Communications and Technology

Lee, Lem \& Grabowski. (2009) Generative Learning Strategies and Metacognitif feedback to Facillitate Comprehension of Science Topics and Self Regulation. Journal of Educational Multimedia and Hypermedia. (online). Jilid 18 no.1 (http://www.proquest.com) diakses 14 Arpril 2012

Linda, Bruce and Dee (2002) Multiple Intelligens Metode Terbaru Melesatkan Kecerdasan. Depok Inisiasi Pers

Nasution, S. (2001). Manejemen Pembelajaran. Jakarta: Bumi Aksara.

Ogunleye and Babajide, (2011) Generative Instructional Strategy Enhances Senior Secondary School Student's Achievement in Physics. European Journal of Educational Studies (online). Jilid 3 No.3 ((http://www.proquest.com) diakses 14 April 2012

Prashnig, Barbara. (2007) The Power of Learning Styles. Bandung : Mizan Utama

Reigeluth, C. M (1983) . Instructional Design Theory and Models. New Jersey : Publisher's Hillsdale
Romizowski, A,J. (1981) Producing Instructional System. New York. Kogan Page. London Nicholas Publishing, (online preview) diakses 14 April 2012

Sadli, Saparinah. (1986) Intelegensi Bakat dan Test IQ. Jakarta : Dian Rakyat

Sanjaya, Wina (2008). Strategi Pembelajaran Berorientasi Standart Proses Pendidikan. Jakarta: Kencana Pers.

Santrock, W. John. (2007) Psikologi Pendidikan. Jakarta : Kencana Prenada Media Group

Sofyanto. (2011). Pengaruh Model Pembelajaran dan Kecerdasan Siswa Terhadap Hasil Belajar Geografi . Tesis Pasca Sarjana Unimed. Tesis tidak diterbitkan

Sudjana. (2005). Metoda Statistika. Bandung : Tarsito

Sukardi. (2005). Metode Penelitian Pendidikan Pendekata. Bandung: Bumi Aksara

Suparman, Atwi. (1997). Design Instructional. Jakarta: PAU-PPAI-UT.

Suryabrata, Sumadi. (2006). Psikologi Pendidikan. Jakarta: Raja Grafindo Persada

Wena, Made. (2009). Strategi Pembelajaran Inovatif Kontemporer: Suatu Tinjauan Konseptual Operasional. Jakarta: Bumi Aksara. 